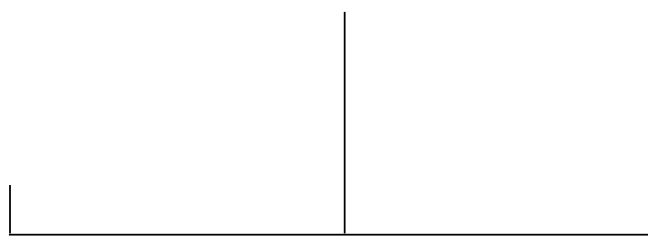

Rev. Latinoam. Psicopat. Fund., São Paulo, v. 15, n. 3, p. 464-481, setembro 2012

\title{
Sexual Difference, Identification and Object Choice in Individuals with Sex Differentiation Disorders*
}

\author{
Adriano Morad Bley, Egberto Ribeiro Turato, \\ Carlos Roberto Soares Freire de Rivorêdo, Roberto Benedito de Paiva e Silva, \\ Andrea Trevas Maciel-Guerra, Antonia Paula Marques-de-Faria, \\ Gil Guerra-Junior, Maria Tereza Matias Baptista
}

Objective: To investigate how sexual identity is structured and also to investigate the relationship between sexual identity, choice of sex object and sexual difference.

Method: Semi-structured interviews were held with seven adult patients who were born with sex differentiation disorders: Two had 5alpha-reductase type-2 deficiency and five had congenital adrenal hyperplasia.

Conclusions: Sex is trauma. Neither male nor female nor any other gender identification implies the choice of sex object, genders of partners or sexual practices.

Key words: Sexual identity, choice of sex object, disorders in sex differentiation, qualitative research

* This article is a reformulation from Dissertation defended by Adriano Morad Bley on 2/28/2009 at the Faculdade de Ciências Médicas - Unicamp, under the title: Qualitative approach of patients with disorders of sexual differentiation. Financial support: Capes - Coordenação de Aperfeiçoamento de Pessoal de Nível Superior (Brasilia, DF, Br). 


\section{Introduction}

A careful review of the medical literature on the treatment of children born with problems of anatomic gender ambiguity shows a clear and generalized commitment to heterosexual normativity. Closed questionnaires containing items such as whether the child would rather wear trousers or a dress are applied in order to verify his or her identity and choice of sexual object even before the children themselves have begun to construct them. This, of course, leads to attributions of gender that are determined by the medical team and their families rather than by the children. In fact, this type of homophobic approach has dominated discussions on this question since the 1950s.

Over the last two decades, through the voices of groups including non-governmental organizations, persons bearing sex differentiation disorders have begun to question when and how one should decide in favor of or against surgical intervention following diagnosis (Diamond $\&$ Sigmudson, 1997). Many such persons and groups have advocated the right of the patients themselves to participate in these decisions. But whenever it becomes impossible to answer the question "Is it a boy or a girl?" by observing a newborn baby's genitals, current medical practice holds that an emergency situation is at hand.

Main Aspects of the Nosological Concepts Used in this Article, as Described in Endocrinology and Medical Genetics

\section{Congenital Adrenal Hyperplasia (CAH)}

This group of disorders is characterized by some deficiency in one or more enzymes involved in the metabolism of cortisol. The condition 
results in the reduction of concentrations of cortisol in the blood and a chronic increase in adrenocorticotropic hormone (ACTH). The most common form of Congenital Adrenal Hyperplasia (CAH) is a 21-hydroxylase deficiency, responsible for almost $95 \%$ of the cases of the classical form of the disorders (Merke \& Bornstein, 2005).

Excessive ACTH stimulation leads to the overproduction of adrenal androgens DHEA (dehydroepiandrosterone) and androstenedione, and this situation may result in modified external genitals in newborn females, ranging from cryptorchidia to typical female configurations with a great deal of variation and ambiguity in external genitals.

Much of the recent literature (Blizzard, 2002; Bradley, 1998; Harrison, 2005; Hughes, 2006; Mazur, 2004) suggests that surgery-based interventions for gender reassignment carried out before the age of six months will imply more favorable prognosis, less gender-related anxiety, and likelihood of more frequent choice of heterosexual sex object.

\section{Five-Alpha-Reductase Type 2 Deficiency}

The normal male sexual differentiation process involves many more genetically determined events than that of females. Therefore, genital ambiguity in $46, \mathrm{XY}$ subjects is more complex in terms of etiological diagnosis, including anomalies in gonadal differentiation (such as true hermaphroditism and gonadal dysgenesis) and male pseudohermaphroditism (such as defects in the synthesis, action or metabolism of androgens). Conversion of testosterone (T) into dihydrotestorene (DHT) is required for full virilization of the external genitals of a male fetus, and virilization is catalyzed by 5 -alpha-reductase type 2 . The activity of 5-alpha-reductase type 2 is genetically impaired in these patients, a factor that, in turn, partially or totally blocks the formation of DHT (Sinnecker et al., 1998).

Type 2 deficiency involves a broad spectrum of phenotypes ranging from nearly external female genitals with or without palpable gonads, through various degrees of genital ambiguity, such as severe hypospadias and urogenital sinuses, to an almost normal male phenotype with cryptorchidism and/or infertility. However, some virilization takes place during the puberty of these individuals through the conversion of $\mathrm{T}$ into DHT by enzyme type 1. Consequently, individuals raised as girls often undergo a postpubertal female-to-male change in "gender identity and role" (Blizzard, 2002; Bradley, 1998; Cohen-Kettennis, 2005).

Prevalence studies report that the majority (63\%) of these type-2 deficiency individuals eventually prefer to be assigned as males after puberty (CohenKettennis, 2005).

Rev. Latinoam. Psicopat. Fund., São Paulo, v. 15, n. 3, p. 464-481, setembro 2012 


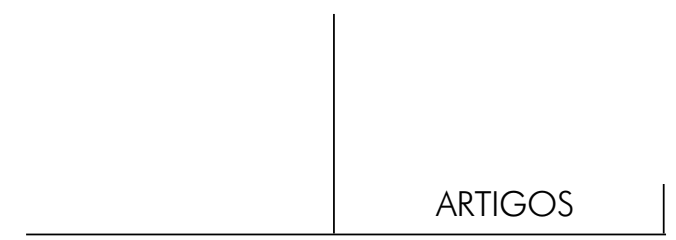

\section{Interviews with Seven Bearers of Sexual Differentiation Disorders}

Semi-structured interviews were held with seven adult patients who showed sexual differentiation disorders at birth. First we will discuss five patients with congenital adrenal hyperplasia (CAH), and then two with 5-alpha-reductase type2 deficiency.

The interviews were conducted on the basis of key questions. In addition, an attempt was made to create a climate that would foster the free association of ideas.

Patients with Congenital Adrenal Hyperplasia (CAH)

A short description of each interviewee is provided below, using fictitious names. Next we will present excerpts from their interviews grouped according to four categories and, finally, comments on and interpretations of their statements.

a) Bianca Antonia (age 27 when interviewed) was born Roberto Antonio and was raised as a boy until puberty, when monthly bleeding through the penis began. During this period, he/she experienced certain events typical of male development, concurrently with symptoms of CAH.

b) Alexandra (age 17 when interviewed) was diagnosed with CAH during the first months of life, then surgically treated and reassigned before the age of one year.

c) Melissa (age 22 when interviewed) was born Francisco but then diagnosed with CAH. As a result, she was reassigned at about two months of age and received the name of Melissa. She underwent corrective surgery sometime before the age of six months.

d) Marialine (age 19 when interviewed) was diagnosed with CAH sometime during the early months of life. She then underwent surgery and gender reassignment before the age of six months.

e) Ana Maria (age 21 when interviewed) was considered male at birth but was soon diagnosed with $\mathrm{CAH}$ and reassigned to female within the first month of life. Her mother began calling her Ana Maria on about the 45th day of life. Definitive external genital surgery was performed at the age of three and onehalf years. 
Fragments from Statements by These Five Patients

The interviews were recorded and then analyzed, with the result that the most striking statements were classified into four categories, namely: a) stages of diagnosis b) treatment, c) family d) Whatfoforme? (The interviewee Bianca seemed to have invented a category of her own, which we include here and translate as: "Whatfoforme?"1)

a) Indications of Stages of Diagnosis Heard in the Patients' Discourse

\section{Bianca}

"They sent me to a sort of specialist; he's called 'nomemembername,' at the Women's Health Center, at Gynecology. They had to do a neoplastia to fix up the first operation. Cause there was a vagina but, there was something else outside, I guess about five centimeters [two inches] long, I think ..."

"I was raised as a boy until I was eight ... Then ... I just had to get it done.... When I was born I guess the doctors said, 'He's a boy but one of his testicles is up inside, and it has to slide down into the sack.",

\section{Alexandra}

"Oh, I found out about my surgery when I was 15 and a doctor came in [to the consulting room] and he wanted to take pictures to see if everything was OK. [...] My mother told me I had a kind of little ball in there and they had to take it out. [...] It was like... there was a penis inside my vagina. I don't know, but that's what my mother said, 'like a sharp prick.' ${ }^{2}$ She said that the thing had gotten bigger, like a big ball, so they operated on me and took it out."

"At the time I felt I wasn't a normal person... Later I thought more about it."

\section{Melissa}

"I know what I have. It's a hormone deficiency. Oh. It was a kind of problem with my sex organs... When I was a little girl, I think I was three, kind of... I had to get an operation."

"In the book the lady doctor showed me what really happened in the past and today, ya know, but there's no difference and it's really normal, and I even

1. Her exact neologism in Portuguese was "praquaprami?"

2. This term in English seems to adequately reflect the double meaning present in the interviewee's original Portuguese ["Como um tipo de picada"]. (TN) 


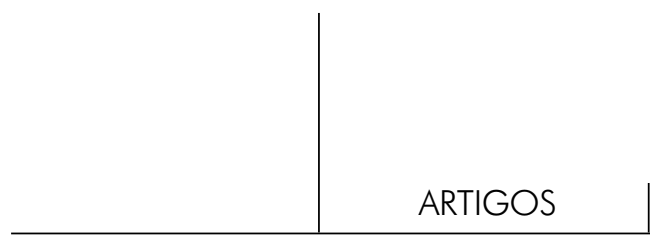

thought I had, if I didn't have any sex it's completely different and not, on the contrary, the only problem at the time was this skin [perhaps clitorimegaly], so there's no difference, see?"3

Interviewer: What name did they put on your first birth certificate?

Melissa: "Francisco. That was my grandfather's name, and then until I didn't discover that $[s i c]$, after I got my new birth certificate, I saw that it was dated August, but I was actually born in May. So I thought 'Oh God, why was there this difference?' I don't remember how old I was, but once a doctor came in and the first thing he said was that I'd never be cured... But why am I in treatment if I can't ever be cured?"

Marialine (referring to her sexual organs): "I was born with problems with my sex organs, so I was born, sort of mixed up. It wasn't just one thing. I had male organs and female organs but my whole body was actually female."

(Talking about what she understands by male and female organs): "A penis and a vagina, all mixed in there with the vagina, and a bump at the top."

Interviewer: "And what was the surgery for?"

Marialine: "To remove my male organ. It was a factory defect, a gland that was born dead, ya know? I think it's something I got from my father and mother and there's this syndrome, ya know? A post-hyperplasia, and that happened to me."

Comments

Bianca condenses terms and creates neologisms in very particular language, perhaps to help her cope with all the confusion she has been through. She wants to know why the doctors didn't notice her problem before she was 8 , and why her surgeries failed to change anything. She lives out her relationship with doctors like a family romance (Freud, 1908-1909).

Bianca's speech pattern was different from that of the other four $\mathrm{CAH}$ patients interviewed. She often gave special stress to the feminine suffix of the adjectives she used, ${ }^{4}$ whereas the others more frequently used adjectives in the

3. The interviewee's original discourse is confused, and transcribed here to show patterns in her speech. (TN)

4. This is especially noticeable in a romance language like Portuguese, where all nouns are either masculine or feminine, and most adjectives have specific forms for the two genders. For example, the adjective "angry" in Portuguese is "bravo" or "brava," depending on the gender of the noun it modifies. When using the word "brava" in reference to herself, Bianca would stress the letter "a" (usual indicative of the feminine gender) much more strongly than she did other vowels in her speech.

Rev. Latinoam. Psicopat. Fund., São Paulo, v. 15, n. 3, p. 464-481, setembro 2012 
masculine. This contrast brings up the question that seems to haunt these subjects as to what signifier should be used for what sex or gender.

Bianca Antonia's attempts at sustaining her gender by stressing the feminine suffixes in her nouns and adjectives also fails, just as the surgeries, the medication and the treatment in general failed, and even the transference with the interviewer. The questions brought up by her discourse might be: "How to define sex through signifiers?" or "How to distinguish male/masculine from female/feminine?"

When Melissa was about fifteen she discovered that a birth certificate issued immediately after she was born bears the name Francisco. A few months later a new certificate was issued, where she appears as Melissa. But the enigma continues as to whether this happened before or after the age of six months, and the consequences involved. The result of her checking her birth certificate and nothing the time that had elapsed between the two dates and that her first name had been the same as her grandfather's, Francisco, led her to say "Until I didn't discover that." With this slip of the tongue she seems to be trying to say that it would be uncomfortable, even traumatic, to discover such a truth at any age.

b) References to Treatment

Bianca: "I've got a uterus and ovaries and I menstruate. I got a neo-vagina in '94, ya know? It's not so good 'cause I feel a lot of pain in the graft they did" (referring to an intravaginal graft of now hairy abdominal skin, which causes her great discomfort during intercourse).

Melissa: "So, as for treatment, being able to talk and exchange ideas, I think it's good, so that way you can know me better, ya know? It's better than just being touched and looked at in the examining room and that's it. I think that's worse, ya know? Treatment has to be [different] for each person."

Marialine: "I have a cell, a kind of a gland, and it supplies something, but it's irregular, so I have to take medicine to regulate this pain."

Ana Maria: "[My surgery] was to fix my vagina, ya know? I was born with it all closed up and they had to open it wider."

\section{Comments}

Ana Maria, Marialine, Melissa and Bianca all spoke openly about their perceptions and feelings and made it clear that the intensity and impacts of diagnosis, treatment and surgical procedures are not proportional to either age or to how much time has gone by since first diagnosis.

Like all human beings, Ana Maria was constituted by her parents' wishes. Ever since she was small Ana Maria has been taken to soccer games by her mother and her maternal grandfather. These moments have been important for the family 


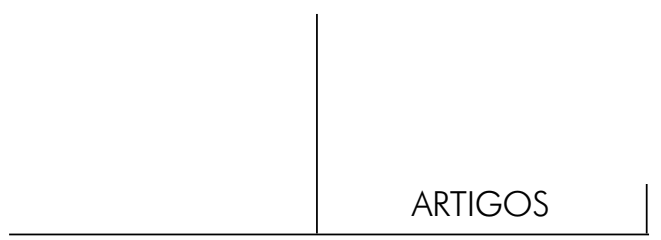

to strengthen emotional ties among its members. One might attribute a masculine gender connotation to interests in certain social or athletic events but, in themselves, they need not be seen as indicators of sexual identification or choice of sex objects.

c) References to Family father?"

Interviewer (to Alexandra): "What made you cry when I asked about your

Alexandra: "It wasn't because my father started giving me more attention after he and my brother started fighting. My dad treats me like I was his son, a boy. I do everything boys do and he's a truck driver and I help him take the truck apart. We moved and I helped him with these things but I think my brother was supposed to do them so, I guess...."

Melissa: "Ya know. It would've been better if my father hadn't hidden this thing. I wish he had been a little bit more mature. He could've talked to me about it. But I don't blame him. I think he just wanted to spare me [the confusion], ya know? But I felt sort of funny about it all. I used to think, 'Why?' 'Why was I a boy first and then a girl and all that mess.' But later on I understood his point of view. Even now he helps me. If he notices that I'm going out in the wrong kind of clothes [according to her father, she sometimes wears 'women's clothing' on the street, but not always], or I don't have earrings on or I'm not wearing lipstick, he makes me go back and straighten out. He wants me to show people I'm a woman."

Interviewer (to Melissa): "What led you go to college to be a lawyer?"

Melissa: "Because of my father. My father studied law, too. And so did my uncle, so I just felt, like, 'they're in law, so I guess I'll be a lawyer, too.' But it's just not that easy. You have to face the course the way it comes."

Interviewer: "And how did you get into playing the drums?"

Melissa: "A cousin of mine invited me. She played in a local church band, so she invited me. I wanted to play the guitar, ya know? But on the way to our first time with the band we stopped by at somebody's house and there was a kid there who played the drums. He sat down and started banging the drums and I thought, 'I don't want to play the guitar anymore. I think I'll learn how to play the drums.",

\section{Comments on References to Family}

After describing the episode when a physician came into the consulting room and asked to photograph her genitals, Alexandra talked about the possibility of her father preferring her over her brother. She blamed her mother for their not having

Rev. Latinoam. Psicopat. Fund., São Paulo, v. 15, n. 3, p. 464-481, setembro 2012 
talked enough about the surgery. She also referred to the new situation where her father prefers her over her brother. The father had given her the opportunity to set up an alliance with him as a way for her to get revenge against her mother.

References by Bianca Antonia to her Own Individual Category: WHATFOFORME?

Bianca: "[The first operation] was to let the testicle move down and they couldn't find it and they put a tube in to hunt for it. I don't know where they were, inside me, and they found a uterus and ovaries and everything was perfect. With time, with the exams, it took a while... at this point she suddenly shouted out "Whatfoforme? [sic, a translated and seemingly nonsensical word.] ${ }^{5}$... My mother wouldn't accept it... and especially not my father."

Comments on the Term "Whatfoforme?"

Not much can be said about Bianca's identification and object choice, largely because she seemed much more preoccupied with her own body, including her obesity (almost $100 \mathrm{~kg}$, according to her), than with other aspects of her life. Might the word "Whatfoforme?" be a substitute for identification? This apparent question might mean a search for some way to work through her sexual and gender identity.

\section{Two Patients Diagnosed with 5-Alpha-Reductase Type 2 Deficiency}

Linus (age 34 when interviewed) was born Lina and raised as a girl until puberty. He is now married (to a woman) and lives in a small town near São Paulo. The couple has one child conceived by in-vitro fertilization.

Marcos (age 20 when interviewed) was Mariane until the age of 13. He lives in a small town in the State of São Paulo, Brazil, has a highschool diploma and works as a bricklayer. He has a girlfriend but he avoids sexual intercourse.

\section{Excerpts from the Interviews}

a) Indications of Stages of Diagnosis in these Patients' Discourse

Linus: "I imagined, ya know, that I got both sexes, but the truth is I was a boy, a little boy, and not a man yet. Then, later on, I started to think, I really don't

5. Her expression was a term she herself invented, namely "Praquaprami?" (TN) 


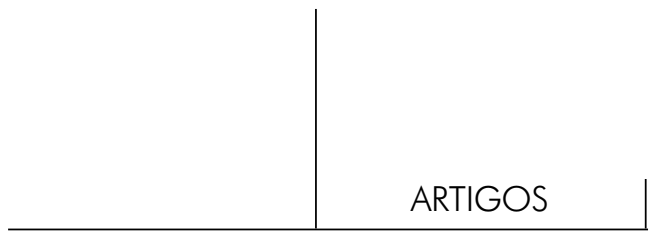

have any sex at all, 'cause the male part didn't develop and the female part didn't either, ya know. So..."

Interviewer: Why did you come here to this clinic? ${ }^{6}$

Linus: "I came for treatment "cause my birth certificate says I used to be a girl, ya know? [The doctor] said [my sex organs are] inside, they' re really small... Man, I don't know if you could ever see anything. I still don't know if you can, ya know?"

Marcos: "I sure can't see it. [The doctors] are the ones who understand it, ya know? They know all about it."

Marcos (Talking about his female-to-male name change and birth certificate at the age of 13): "It was a big surprise 'cause I didn't know anything about all this, ya know? I just went from one place to another to change my name and everything... I had to get exams and everything and it turned out that I didn't have ..., Uhm, I didn't have kind of a ..., a, you know ... I only had testicles, I had men's stuff, you know?"

Interviewer (to Marcos): "Just where are your testicles?"

Marcos: "Inside here, where my vagina is. It's a little bit inside, ya know, hidden away?"

Interviewer (to Marcos): "What do you like most about your body?"

Marcos: "My hair. [He was wearing a ponytail at the time of the interview] I wouldn't change it. Sometimes I think about changing it, then I decide not to."

b) References to childhood

Linus: "I really could've been what I was. What I am today, ya know?"

Interviewer (to Linus): "How did you get along with other kids at school?"

Linus: "Cause I... I was a boy, a guy, ya know? It was hard to have everybody calling me Lina, and I didn't go for all that small talk that girls like so much..."

Interviewer (to Linus): "What about your teenage years?"

Linus: "I first noticed my balls, my testis, when I was eleven. I called them a little bulge, ya know? I told my mother I saw "em and I thought it was kind of strange. I have a bulge between my legs."

Interviewer (to Linus): "You said people saw you as hermaphrodite. How did you feel about that?"

Linus: "I saw myself as a woman, a g-girl who had a problem... One teacher said that, when I was 18 or so, they were gonna put breasts on me and I'd be a

6. GIEDDS: Interdisciplinary Study Group for Sex Differentiation and Determination - Unicamp.

Rev. Latinoam. Psicopat. Fund., São Paulo, v. 15, n. 3, p. 464-481, setembro 2012 
normal woman. That was something I kept thinking about. But, for me, to have 'things' [breasts] up here [would be awful], you know what I mean, don't ya, man?"

Interviewer (to Marcos): "What was it like to get a doll for a present?"

Marcos: "I said I didn't like it, ya know? I didn't like dolls, even when my grandmother said she was going to buy a doll for me. I said I didn't like dolls and I hid 'em. I still have one or two put away someplace."

Interviewer (to Marcos): "Why keep them?"

Marcos: "Everything's hidden away, everything. Oh, my grandmother keeps 'em, ya know?"

Interviewer (to Marcos): "And what about your feelings of embarrassment?"

Marcos: "Oh. They called me all kinds of things, you know [starts to cry], like 'dyke,' 'faggot,' 'queer,' and I don't know what else, 'homo,' things like that."

c) References to Family

Linus: "I'm sure [my parents] wanted to have a son."

Comments on Marcos and Linus

Both Marcos and Linus eventually chose to live as males.

Linus lives out the masculinity his parents wanted, and he expressed this in the following words: "There's no doubt they wanted to have a boy." His identity seems to have been constructed in his choice of clothing and games during childhood, as communicated by the adults around him.

Marcos, on the other hand, did not talk about any of his childhood "boytype" games or toys, but about the dolls he received and later carefully hid away. "I still have one or two," he said. When referring to his male sex organs he also said they were "hidden away." His condition as a male also seems to have been hidden away when children in the neighborhood indiscriminately called him a "dyke," a "queer," or "a sissy." He seems not to have noticed the differences in gender of these terms. Was he denying his identity? Or was he even clearly aware of the differences between the two socially accepted gender identities? Might this aspect have been foreclosed? 


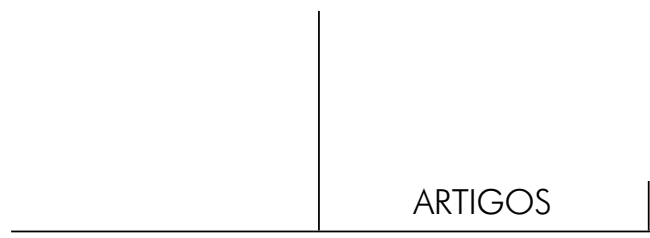

Remarks on Theoretical Aspects Involved

As Freud (1921 [1955]) once wrote, "Identification is [...] the earliest expression of an emotional tie with another person" (p. 134). But there is yet another type of early tie, known in psychoanalysis as object choice. Freud's study of the neuroses led him to state that, in their love relationships, neurotics transit back and forth between identifications and object choices: "Identification has appeared instead of object choice, and that object choice has regressed to identification" (Freud, 1921 [1955], p. 136). Within the present-day theory of the unconscious, what should we consider as the place for identification, and the place for object choice? What does it mean to say that one (identification) can appear in the place of the other (object choice)?

According to Jacques Lacan, "The unconscious is structured like a language" (Seminar Book 20, p. 25). From this point of view, how might one see transitions between identification and object choices? Are identifications metaphors that a subject constructs of him or herself throughout life, with metonymies constituting object choices? In this case, could it be said that a subject inserts a metaphor in the place of a metonymy, and vice-versa? In any case, identifications and object choices, sexual differences, metaphors and metonymies are all linguistic constructs that belong to the field of love.

But sex, in contrast, belongs to a different field, structured by trauma. The sexual practices of human beings consist of that which cannot be said about the trauma. This realization led J. Lacan to utter his famous phrase: "There is no sexual relationship," in the sense of not-whole sex in the human being. The reference to the not-whole of the female body and the also impossible task of ceasing to say about sexual difference, bring up some important questions.

From a historical, cultural and socio-economic perspective today, this not ceasing to want to say about sexual difference assumes in sexual jouissance a prevalence of phallic jouissance in prejudice to the not-whole jouissance.

The feminine position and women's jouissance thus remained in tow, until the "revolution of hysteria" perceived by Freud. This historical moment occurred as $19^{\text {th }}$ century women invested in their bodies as questions about and resistence to the anatomic/pathological totalization of positivist science, thus structuring an Other jouissance in contrast to male jouissance.

But since the beginning of new feminist positions of the early 1960s, with the spread of contraceptive methods and the resulting individual choice of whether or not one wants to become pregnant from a sexual relationship, a new reality has emerged.

Women's jouissance was first seen as an Other jouissance, different from men's, and hysterical women were taken as the "place," or "reservoir" for this 
alterity. With the predominance of phallic jouissance, this "reservoir," or "place," became empty or, we might say, it simply faded away.

Today the signifier sexual difference would seem to find in the body of the child what, in earlier times, seemed to be in the female body. Feminine jouissance and sexual difference is apparently being displaced to the body of the child. What would that mean to mankind?

\section{Final Considerations}

The signifiers we use to try to name, or classify, human beings in terms of their choice of objects and their sexual identification - terms, therefore, aimed at indicating sexual differences, are all failures. In other words, terms such as heterosexual, homosexual, active, passive, transsexual, transvestite/ cross-dresser, and so forth, must all be considered inadequate attempts at indicating sexual difference, sexual identification and the choice of sex object.

There is no ideal moment to perform surgical reassignment interventions on intersex patients, since the depth of the trauma can be neither predicted nor avoided. Traumatic events and their numerous occurrences are overdetermined, and depend on how parents, medical teams and subjects themselves cope with them throughout life. This fact is closely related to the question of how and when to operate, and who makes any decision to operate in order to "normalize" "abnormal" sex organs. The subject should never be left out of this decision.

This most complex discussion involves many variegated factors, including $\mathrm{X}$ and $\mathrm{Y}$ chromosomes, testosterone levels, hormone receptor sensitivities, sexual practices, the gender of partners, mannerisms, clothing, accessories, dream content and sexual fantasies, and none of them determine individuals' identification nor their preferences for this or that sexual object.

\section{Acknowledgments}

Special thanks to Dra. Sofia Helena Vicente de Lemos Marini for presenting the CAH early treated and diagnosed patients.

\section{References}

Blizzard, R.M. Intersex Issues: A Series of Continuing Conundrums. Pediatrics, v. 111, n. 3, p. 616-621, 2002. 


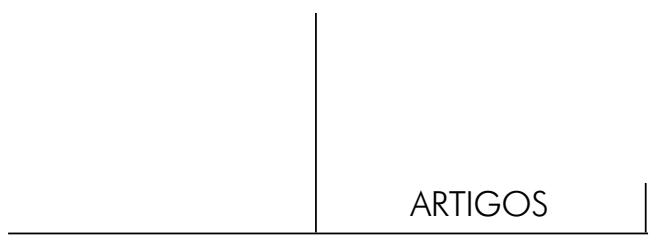

Bradley, S.J. at al. Experiment of Nature: Ablatio Penis at 2 Months, Sex Reassignment at 7 Months, and a Psychosexual Follow-up in Young Adulthood. Pediatrics, v. 102, n. 1, p. e9, 1998.

Cohen-Kettennis, P.T. Gender change in 46, XY persons with 5[alpha]-reductase-2 deficiency and 17 [beta]-hydroxysteroid dehydrogenase-3 deficiency. Archives of Sexual Behavior, v. 34, n. 4, p. 399, 2005.

Damiani, D.; Guerra-JR., G. As novas definições dos estados intersexuais: o que o Consenso de Chicago contribui para o estado da arte? Arquivos Brasileiros de Endocrinologia \& Metabologia, v. 51, n. 6, p. 1013-17, 2007.

Diamond, M.; Sigmundson, H.K. Management of intersexuality-Guidelines for dealing with persons with ambigous genitals. Archives of Pediatrics Adolescent, n. 151, p. 1046-50, 1997.

Freud, S. (1905). Três ensaios sobre a teoria da sexualidade. In: Edição Standard Brasileira das Obras Psicológicas Completas de Sigmund Freud. Rio de Janeiro: Imago, 1996. V. VII, p. 119-218.

Freud, S. (1909[1908]). Romances familiares. In: Edição Standard Brasileira das Obras Psicológicas Completas de Sigmund Freud. Rio de Janeiro: Imago, 1996. v. IX, p. 219-222.

Freud, S. (1921). Psicologia de grupo e a análise do ego. In: Edição Standard Brasileira das Obras Psicológicas Completas de Sigmund Freud. Rio de Janeiro: Imago, 1996. v. XVIII, p. 79-154.

Freud, S. (1921). Group Psychology and the Analysis of the Ego. London: Penguin Books, 1991. v. 12.

HARRISON, J. Pink, lavender and grey: Gay, lesbian, bisexual, transgender and intersex ageing in Australian gerontology. Gay and Lesbian Issues and Psychology Review, v. 1, n. 1, p. 11-6, 2005.

Hughes, I.A. et al. Consensus statement on management of intersex disorders.

Journal of Pediatric Urology, v. 2, n. 3, p. 148-62, 2006.

LACAN, J. A identificação. Seminário de 1961-1962. Tradução do Centro de Estudos Freudianos do Recife, 2003.

LEE, P.A. Consensus Statement on Management of Intersex Disorders. Pediatrics, v. 118, n. 2, p. e488-e500, August 2006.

MAzUR, T. et al. Male Pseudohermaphroditism: Long-term quality of life outcome in five 46, XY individuals reared female. Journal of Pediatric Endocrinology and Metabolism, n. 17, p. 809-23, 2004.

Merke, D.P.; Bornstein, S.R. Congenital Adrenal hyperplasia. Lancet, v. 365, n. 9477, p. 2125-36, 2005.

Rev. Latinoam. Psicopat. Fund., São Paulo, v. 15, n. 3, p. 464-481, setembro 2012 
Meyer-Bahlburg, H.F.L. Gender dysphoria and gender change in persons with intersexuality. Archives of Sexual Behavior, v. 34, n. 4, p. 371-3, 2005.

Money, J. A first person history of pediatric psychoendocrinology. Perspectives in sexuality series New York: Plenum Publishers, 2002. Reimpressão da $1^{\mathrm{a}}$ edição, p.1-51.

SiNNECKER et al. Phenotypic classification of male pseudohermaphroditism due to Steroid 5 alpha Reductase 2 Deficiency. Amercian Journal of Medical Genetics, v. 63 , n. 1 , p. 223-230, 1996.

ZuCKER, K.J. Measurement of psychosexual differentiation. Archives of Sexual Behavior, v. 34, n. 4, p. 375-88, 2005.

Zucker, K.J.; Bradley, S.J.; Oliver, G.; Blake, J.; Fleming, S.; HoOd, J. Self-reported sexual arousability in women with congenital adrenal hyperplasia. Journal of Sex and Marital Therapy, v. 30, n. 5, p. 343-355, 2004.

\section{Resumos}

(Diferença sexual, identificação e escolha de objeto em pacientes com distúrbios da diferenciação sexual)

Objetivo: Interrogar como se estrutura a identidade sexual. Investigar as relações entre identidade sexual, escolha de objeto sexual e diferença sexual.

Método: Aplicamos entrevista semi-estruturada em pacientes com distúrbios da diferenciação sexual: 2 com deficiência da 5 alfa redutase tipo 2 e 5 com Hiperplasia Adrenal Congênita.

Conclusões: Sexo é trauma. Identificação masculina, feminina ou outras não implicam no sexo do objeto de escolha, gênero dos parceiros ou práticas sexuais.

Palavras-chave: Identidade sexual, escolha de objeto sexual, distúrbios da diferenciação sexual, pesquisa qualitativa

(Différence sexuelle, identification et choix d'objet parmi des patients porteur de troubles de différenciation sexuelle)

Objectif: Ce travail a pour but d'analyser la façon comment l'identité sexuelle se structure, ainsi que d'investiguer les rapports entre l'identité sexuelle, le choix de l'objet sexuel et la différence sexuelle.

Méthode: Entrevue semi-dirigée de patients porteur de troubles de différenciation sexuelle: Deux patients porteurs du déficit 5-alpha réductase type 2 et cinq patients porteurs d'hyperplasie congénitale des surrénales.

Conclusion: Le sexe est un traumatisme. L'identification masculine, féminine ou autre n'implique pas le sexe de l'objet du choix, le genre des partenaires ou les pratiques sexuels.

Rev. Latinoam. Psicopat. Fund., São Paulo, v. 15, n. 3, p. 464-481, setembro 2012 


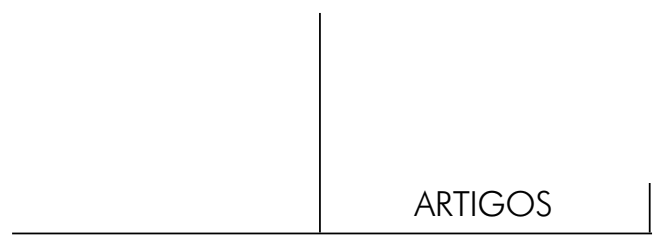

Mots clés: Identité sexuelle, choix de l'objet sexuel, troubles de différenciation sexuelle, recherche qualitative

(Diferencia sexual, identificación e elección de objeto en pacientes con anomalías de la diferenciación sexual)

Objetivo: Interrogar como se estructura la identidad sexual. Investigar las relaciones entre identidad sexual, elección de objeto sexual y diferencia sexual.

Método: Fueron aplicadas entrevistas semiestructuradas en pacientes con trastornos en la diferenciación sexual: 2 con deficiencias de la 5 Alpha Redutase tipo 2 y 5 con Hiperplasia Adrenal Congénita.

Conclusión: Sexo es trauma. Identificación masculina, femenina u otras no implican en el sexo del objeto de elección, el género de los compañeros (partenaires) o prácticas sexuales.

Palabras clave: Identidad sexual, elección de objeto sexual, trastornos en la diferenciación sexual, investigación cualitativa

(Sexueller Unterschied, Identifizierung und Wahl des Gegenstandes bei Patienten mit Geschlechtsidentitätsstörungen)

Ziel: Hinterfragen, wie sich die geschlechtliche Identität strukturiert. Die Wechselbeziehungen zwischen sexueller Identität, Wahl des sexuellen Objektes und sexuelle Andersartigkeit untersuchen.

Methode: Wir führen teilweise strukturierte Interviews mit Patienten mit Geschlechtsidentitätsstörungen: 2 mit der Störung Alpha 5 Reduktase Typ 2 und 5 mit kongenitaler adrenaler Hyperplasie (CAH).

Schlussfolgerung: Sex ist ein Trauma. Männliche, weibliche und andere Identität deutet nicht auf das Geschlecht des Wahlgegenstandes, das Geschlecht der Partner oder die sexuellen Praktiken.

Schlüsselwörter: Sexuelle Identität, Wahl des sexuellen Gegenstandes, Geschlechtsidentitätsstörungen, qualitative Studie

Citação/Citation: Bley, A.M.; Turato, E.R.; RivorÊDo, C.R.S.F.; Paiva E Silva, R.B.; MacielGuerra, A.T.; Marques-De-Faria, A.P.; Guerra-Junior, G.; Baptista, M.T.M. Sexual difference, identification and object choice in individuals with sex differentiation disorders. Revista Latinoamericana de Psicopatologia Fundamental, São Paulo, v. 15, n. 3, p. 464-481, setembro 2012.

Editor do artigo/Editor: Prof. Dr. Manoel Tosta Berlinck

Recebido/Received: 9.6.2011 / 6.9.2011 Aceito/Accepted: 5.11.2011 / 11.5.2011

Rev. Latinoam. Psicopat. Fund., São Paulo, v. 15, n. 3, p. 464-481, setembro 2012 


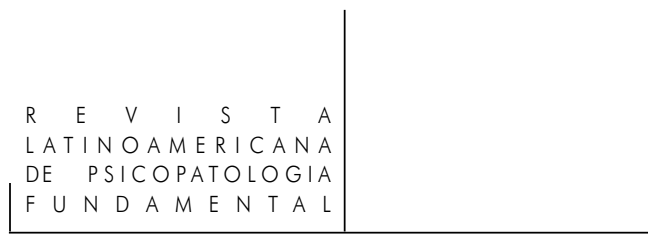

Copyright: () 2009 Associação Universitária de Pesquisa em Psicopatologia Fundamental/ University Association for Research in Fundamental Psychopathology. Este é um artigo de livre acesso, que permite uso irrestrito, distribuição e reprodução em qualquer meio, desde que o autor e a fonte sejam citados/This is an open-access article, which permits unrestricted use, distribution, and reproduction in any medium, provided the original author and source are credited.

Financiamento/Funding: Esta pesquisa é financiada pela CAPES - Coordenação de Aperfeiçoamento de Pessoal de Nível Superior / This research is funded by the CAPES - Coordenação de Aperfeiçoamento de Pessoal de Nível Superior.

Conflito de interesses/Conflict of interest: Os autores declaram que não há conflito de interesses / The authors declare that has no conflict of interest.

\section{Adriano Morad Bley}

Médico Endocrinologista; Psicanalista; Mestre em Saúde da Criança e do Adolescente pela Faculdade de Ciências Médicas da Universidade Estadual de Campinas - Unicamp (Campinas, SP, Br).

Av. Princesa D'Oeste, 1212/112B

13100-900 Campinas, SP, Br

Fone: (19) 9633-8410

e-mail: adrianobley@gmail.com

\section{Egberto Ribeiro Turato}

Médico e livre-docente do Departamento de Psicologia Médica e Psiquiatria da Faculdade de Ciências Médicas da Universidade Estadual de Campinas - Unicamp (Campinas, SP, Br).

Cidade Universitária Zeferino Vaz - Barão Geraldo

13083-970 Campinas, SP, Br

Fone: (19) 3521-9295

e-mail: erturato@uol.com.br

\section{Carlos Roberto Soares Freire de Rivorêdo}

Médico e doutor do Departamento de Pediatria da Faculdade de Ciências Médicas da Universidade Estadual de Campinas - Unicamp (Campinas, SP, Br).

Rodovia Nilo Máximo, 5752 - Santo Antonio da Boa Vista

12315-010 Jacareí, SP, Br

e-mail: carrivo@uol.com.br

\section{Roberto Benedito de Paiva e Silva}

Psicólogo e doutor do Centro de Pesquisas em Reabilitação da Faculdade de Ciências Médicas da Universidade Estadual de Campinas - Unicamp (Campinas, SP, Br).

Alameda Rio Tocantins, 266 - Condomínio Morro Vermelho

13807-808 Mogi Mirim, SP, Br

e-mail: rbdpas@uol.com.br 


\section{ARTIGOS}

\section{Andrea Trevas Maciel-Guerra}

Médica e titular do Departamento de Genética Médica da Faculdade de Ciências Médicas da Universidade Estadual de Campinas - Unicamp (Campinas, SP, Br).

Cidade Universitária Zeferino Vaz - Barão Geraldo

13083-970 Campinas, SP, Br

e-mail: atmg@ @fcm.unicamp.br

\section{Antonia Paula Marques-de-Faria}

Médica e livre-docente do Departamento de Genética Médica da Faculdade de Ciências Médicas da Universidade Estadual de Campinas - Unicamp (Campinas, SP, Br).

Cidade Universitária Zeferino Vaz - Barão Geraldo

13083-970 Campinas, SP, Br

e-mail: apmfaria@fcm.unicamp.br

\section{GiL GuerRa-Junior}

Médico e livre-docente do Departamento de Pediatria da Faculdade de Ciências Médicas da Universidade Estadual de Campinas - Unicamp (Campinas, SP, Br).

Caixa Postal 6111

13083-100 Campinas, SP, Br

e-mail: gilguer@fcm.unicamp.br

\section{Maria Tereza Matias Baptista}

Médica e doutora do Departamento de Clínica Médica da Faculdade de Ciências Médicas da Universidade Estadual de Campinas - Unicamp (Campinas, SP, Br).

Rua Emilio Ribas, 805/41 - Cambui

13100-900 Campinas, SP, Br

Fone: (19) 3252-5885

e-mail: endoplastic@uol.com.br / terma@uol.com.br 